Hypothesis

\title{
Genetic Hypothesis and Pharmacogenetics Side of Renin-Angiotensin-System in COVID-19
}

\author{
Donato Gemmati ${ }^{1,2,3, *(\mathbb{B})}$ and Veronica Tisato ${ }^{1}$ (]) \\ 1 Department of Morphology, Surgery and Experimental Medicine, University of Ferrara, 44121 Ferrara, Italy; \\ veronica.tisato@unife.it \\ 2 Centre Hemostasis \& Thrombosis, University of Ferrara, 44121 Ferrara, Italy \\ 3 University Centre for Studies on Gender Medicine, University of Ferrara, 44121 Ferrara, Italy \\ * Correspondence: d.gemmati@unife.it
}

Received: 20 July 2020; Accepted: 2 September 2020; Published: 3 September 2020

\begin{abstract}
The importance of host genetics and demography in coronavirus disease 2019 (COVID-19) is a crucial aspect of infection, prognosis and associated case fatality rate. Individual genetic landscapes can contribute to understand Severe Acute Respiratory Syndrome Coronavirus 2 (SARS-CoV-2) burden and can give information on how to fight virus spreading and the associated severe acute respiratory distress syndrome (ARDS). The spread and pathogenicity of the virus have become pandemic on specific geographic areas and ethnicities. Interestingly, SARS-CoV-2 firstly emerged in East Asia and next in Europe, where it has caused higher morbidity and mortality. This is a peculiar feature of SARS-CoV-2, different from past global viral infections (i.e., SARS-1 or MERS); it shares with the previous pandemics strong age- and sex-dependent gaps in the disease outcome. The observation that the severest COVID-19 patients are more likely to have a history of hypertension, diabetes and/or cardiovascular disease and receive Renin-Angiotensin-System (RAS) inhibitor treatment raised the hypothesis that RAS-unbalancing may have a crucial role. Accordingly, we recently published a genetic hypothesis on the role of RAS-pathway genes (ACE1, rs4646994, rs1799752, rs4340, rs13447447; and $A C E 2$, rs2285666, rs1978124, rs714205) and ABO-locus (rs495828, rs8176746) in COVID-19 prognosis, suspecting inherited genetic predispositions to be predictive of COVID-19 severity. In addition, recently, Genome-Wide Association Studies (GWAS) found COVID-19-association signals at locus 3p21.31 (rs11385942) comprising the solute carrier SLC6A20 (Na+ and Cl-coupled transporter family) and at locus 9q34.2 (rs657152) coincident with ABO-blood group (rs8176747, rs41302905, rs8176719), and interestingly, both loci are associated to RAS-pathway. Finally, ACE1 and ACE2 haplotypes seem to provide plausible explanations for why SARS-CoV-2 have affected more heavily some ethnic groups, namely people with European ancestry, than Asians.
\end{abstract}

Keywords: ACE1; ACE2; RAS-pathway; COVID-19; SARS-CoV-2; prognostic markers; gender-gap

\section{Introduction}

The novel Severe Acute Respiratory Syndrome Coronavirus 2 (SARS-CoV-2), responsible for the coronavirus disease 2019 (COVID-19), enters human cells by binding its spike protein to the membrane receptor angiotensin converting enzyme 2 (ACE2) and interacting with the transmembrane serine protease 2 (TMPRSS2, widely expressed in epithelial cells at the respiratory, gastrointestinal and urogenital levels), leading to unrestrained ACE2 downregulation [1,2]. The main physiological role of ACE2 is to counteract ACE1 actions within the renin-angiotensin-system (RAS), by converting the potent vasoconstrictor angiotensin-II (Ang-II) in the vasodilator Ang1-7, crucial in controlling the local tissue homeostasis by anti-inflammatory, anti-coagulant, anti-proliferative and anti-fibrotic activity [2]. 
Previous studies in animal models suggested that RAS-antagonists upregulate ACE2 expression [3-6], though human studies showed conflicting results [7-9], raising the concern that higher ACE2 receptor levels might favor SARS-CoV-2 infection. Accordingly, among RAS-antagonists, ACE-inhibitors (ACEi) or angiotensin-receptor blockers (ARBs) have been suspected to be risky in COVID-19 patients [10,11]. Moreover, the observation that patients affected by cardiovascular diseases, hypertension, kidney disease and diabetes, in which RAS-antagonists represent a standard care, are overrepresented among the severest COVID-19 cases, raised concerns on discontinuing or not RAS-antagonist treatment. On the other hand, higher baseline ACE2 levels have been reported in children, young people and women that are characterized with better prognosis, mild symptoms and lower case fatality rate (CFR) during COVID-19 [12-15]. Of note, ACE2 cellular density or availability is determinant in maintaining normal tissue homeostasis, thus, ACE2 activators or soluble form of recombinant human ACE2 have been suggested to treat COVID-19 patients [16-19]. Considering that SARS-CoV-2 infection downregulates cellular ACE2 expression, any action aimed to reestablish ACE1/ACE2 balance might contribute in restoring tissue homeostasis and counteracting lung or other organ failure.

To clarify this issue and weight the risk-benefit ratio of RAS-antagonists use in COVID-19, several observational studies and case-control studies have been published reporting no evidence of increased in-hospital death, disease severity or risk of SARS-CoV-2 infection in continuing ACEi or ARBs treatment [20-22]. Overall, these observations cannot be considered the proof of concept for promoting such drugs in every COVID-19 patient, though consensus and recommendations coming from several international societies stated not to stop RAS-antagonist treatments in cardiovascular disease patients with COVID-19 [23,24]. In this line, RAS inhibitors in COVID-19 have been recently discussed [2,25].

Interestingly, ACE1 and ACE2 mutual levels, as well as RAS-antagonists' response, are strongly regulated by common genetic variants in their genes as well as by other genes out from the RAS-pathway. Of note, wide sex and racial differences in the frequency of $A C E 1$ and $A C E 2$ gene variants have been reported [26,27], and selected haplotypes cluster in fragile subgroups of patients at high risk of COVID-19 poor prognosis (e.g., male sex, Black ethnicity, cardiovascular disease), and interestingly, they seem to overlap COVID-19 morbidity and mortality rates [2,28-32]. Together with environmental factors, host genetics and ethnic variations could indeed account for the extreme wide range of SARS-Co-2 symptoms observed among different populations. This is the case of South Asia, in which, despite a vast population, restricted health infrastructures and a recent rush in the number of COVID-19 cases, the mortality rate is lower than in Western Europe and North America [27]. Explanations and mechanisms for this assumed "protection" have not been established yet, though ACE1 and ACE2 genes have been proposed as a possible underlining mechanistic reason due to their extremely different gene expression and gene haplotypes distribution between Asians and Caucasians [26,27]. However, gene analyses yielded conflicting data and controversial results are still debated considering different ethnicities $[2,27,28,32,33]$. Realistically, the burden of genetic predispositions should be considered in the contest of the specific environment in which they exert their actions. Accordingly, social variables such as local health systems, government decisions and people's collective behaviors are expected to have strong part in the global outcome. As recently reported, there is an imperative need for basic research in environmental sciences on SARS-CoV-2 to allow the identification of specific environmental factors modifying infectivity, severity and spread of COVID-19 [34,35]. Aware of the crucial role of these aspects, we will here focus our main attention on the genetic side of such complex circumstance advising for next dedicated specific investigations.

Specifically, we here propose and discuss about a genetic hypothesis on the RAS unbalancing and over-activation after SARS-CoV-2 infection mainly caused by enhanced Ang-II signaling as a one of the primary drivers of COVID-19 pathobiology and severity. These could potentially be the bases for a genetic score of at risk patients, according to their definite genetic background and ethnicity. Although this could explain part of the variance in the spreading of SARS-CoV-2, further dedicated studies aimed 
at revealing how the different host susceptibility interact with the local environment could help in recognizing the effective dedicated measures to intervene and counteract next waves of virus infection.

\section{ACE1/ACE2 Balance}

The complex dynamic in the formation of angiotensin peptides mainly depends on two antagonist enzymes ACE1 (EC 3.4.15.1), involved in the local vasoconstrictor/proliferative axis (ACE1/Ang-II/AT1 receptor), and ACE2 (EC 3.4.17.23), involved in the vasodilator/anti-proliferative axis (ACE2/Ang1-7/MAS receptor). Most of ACE1 is bound to tissues with lungs (luminal surface of endothelial cells in lungs vasculature), testis and kidney (endothelial cells, mesangial cells and epithelial cells from the proximal tubule and distal regions of the nephron) containing abundant amounts of ACE1, though the circulating enzyme is also present in the blood [36,37]. With regard to ACE2, the protein is mainly localized in lung alveolar epithelial cells and enterocytes of the small intestine as well as in endothelial cells and smooth muscle cells of pulmonary and extra-pulmonary organs [38]. In the context of the RAS pathway, they work in synergy to maintain the hemodynamic stability preserving in turn endothelial and organs integrity. Many other enzymes and receptors are involved in this crucial pathway as summarized in Figure 1. Inherited and/or acquired alterations of the mediators belonging to this pathway might create disequilibrium affecting anti-inflammatory, anticoagulant, anti-proliferative, anti-fibrotic, anti-apoptotic and anti-oxidant activities as during hypertension, cardiovascular and kidney diseases, leading to organ dysfunction and failure. To counteract RAS over-activation and reestablish ACE1/ACE2 balance, ACEi and ARBs show high efficacy in contrasting Ang-II levels/action by increasing Ang 1-7 or blocking Ang-II type 1 receptor (AT1R), respectively (Figure 1).

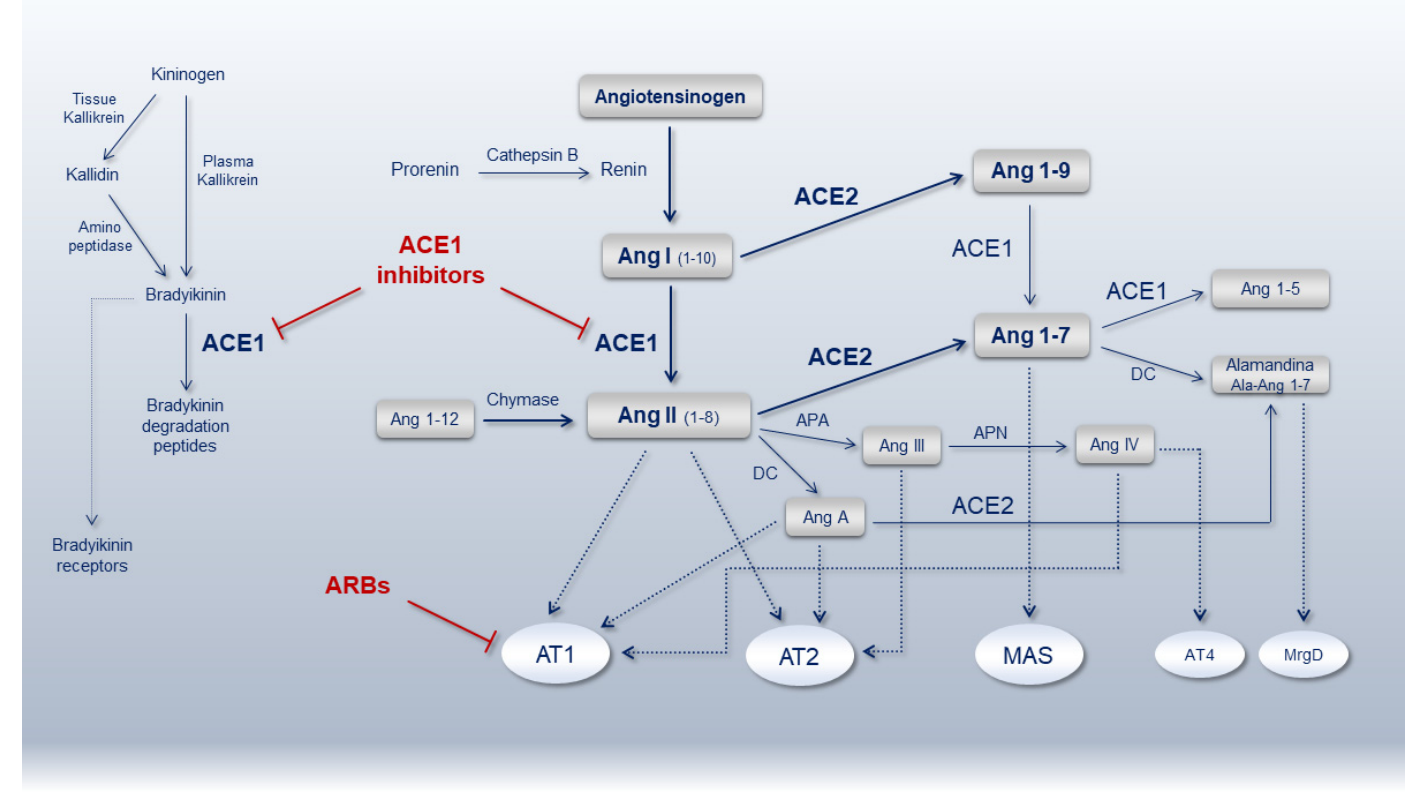

Figure 1. Schematic representation of the renin-angiotensin-system (RAS) pathway showing the main bioactive peptides and key receptors. ACE1, angiotensin-converting enzyme 1; ACE2, angiotensin-converting enzyme 2; Ang, angiotensin; AT1R, Ang-II type 1 receptor; AT2R, Ang-II type 2 receptor; ARBs, angiotensin receptor blockers; MAS, Mas receptor; AT4R, angiotensin receptor type 4; MrgD, MAS-related G protein-coupled receptor member D; APA, aminopeptidase A; APN, aminopeptidase N; DC, decarboxylase.

Several studies assessing the inhibition of Ang-II signaling in pulmonary injury, acute respiratory distress syndrome (ARDS), pulmonary fibrosis and lung damage, confirmed the benefits of ACEi or ARBs treatment by softening cell apoptosis, fibrosis and inflammatory cytokines (CKs) release [39-41]. One of the goals of this approach is to restore the physiological ACE1/ACE2 balance in favor of 
ACE2-derived peptides. During pathological conditions, such as SARS-CoV-2 infection, suppression of ACE2 due to virus binding alters the ACE1/ACE2 balance in favor of Ang-II overproduction, improving ADAM17 activity (a metallopeptidase expressed by most mammalian cells including lung bronchial epithelial cells, vascular smooth muscle cells and macrophages [42]) responsible for ACE2 shedding further decreasing ACE2-membrane in a vicious detrimental loop [2,43]. On the other hand, some authors cautioned against the use of these drugs, hypothesizing that ACEi/ARBs might increase the risk and spreading of infection or develop severe COVID-19 by increasing ACE2 expression [44]. Other studies pointed on the development of adverse pharmacogenetics interactions and negative side effects such as hypotension, dry cough or hyperkalemia in an appreciable proportion of patients [45].

Two crucial aspects relate to ACEi/ARBs treatments: i) stopping or continuing drugs in already-treated patients regardless of SARS-CoV-2 infection; ii) hypothesizing a repositioning of such drugs in SARS-CoV-2 infected patients to efficiently restore ACE1/ACE2 balance and contrast disease worsening. Accordingly, it has been recommended to not stop RAS-antagonists in already-treated patients [23,24], and recent papers argued that RAS-inhibitors repositioning during COVID-19 emergency does not compare to what has been done for anti-inflammatory, anti-malaria and anti-coagulant drugs [2,45]. Although there is a recognized association between COVID-19 and coagulopathy, and the disease score severity is positively correlated with pro-coagulant markers (e.g., high D-dimer and fibrinogen levels), accurate risk-benefit evaluations should be considered particularly in severe COVID-19 patients. Indiscriminate anticoagulants administration may increase the risk of spontaneous hemorrhage, heparin-induced thrombocytopenia (HITP) and anti-PF4-heparin complex antibodies formation [46-50]. Finally, in addition to the kind of heparin used for patients' treatment (i.e., LMWH versus HMWH), individual bleeding and thrombotic risk should be considered both during hospitalization and in post-discharge COVID-19 patients [51,52].

Genetically determined ACE1/ACE2 mutual ratios can give back different susceptibilities and predispositions to SARS-CoV-2 progression and infection, responsible in part for different COVID-19 prognosis and mortality, and such information could be useful to pharmacogenetically combine the best drug-user matching and repositioning [2].

\section{ACE1 and ACE2 Genes}

ACE1 gene maps on chromosome 17 (locus 17q23.3), it comprises 26 exons accounting for a full-length gene of about $21 \mathrm{~kb}$, coding for a gene product of 1306 aa (Genbank, NT010783) responsible for the conversion of Ang-I to Ang-II. Several gene variants influence ACE1 expression accounting for a wide range of levels in different populations. Among the most relevant, a common insertion/deletion (I/D) of 287-bp in the Alu-sequence of intron 16, represented by four individual SNPs (rs4646994, rs1799752, rs4340 and rs13447447), modulates ACE1 expression [53]. The presence of Alu-elements may cause an alternative splicing responsible for protein shortening and the loss of one of the two enzyme active sites in the ACE1 I-allele, while the counterpart D-allele still maintains the two active sites favoring Ang-I to Ang-II formation [54,55]. Accordingly, the D/D genotype shows the highest serum/tissue ACE1 activity, the I/D genotype shows intermediate levels, and the I/I genotype the lowest ACE1 level [56].

A worldwide geographic genetic analysis showed a decline of the D-allele from the highest frequency in African and Arab regions (0.57-0.88), where it appeared as an ancestral allele, towards the lowest frequency in East-Asia (0.12-0.27) with intermediate frequencies in Europe, Australia and America [57]. The D-allele have had some advantages for humans in hot-and-dry environments to retain salt and water. After humans expanded out of Africa, where the climate gradually becomes colder-and-wetter, the propensity to retain salt and water become deleterious, as it increases genetic susceptibility to hypertension and other hypertension-related diseases such as cardiovascular disease and diabetes accordingly with the "thrifty genotype" hypothesis [57]. The Online Mendelian Inheritance in Man (OMIM), a catalogue of human genes and genetic disorders focused on gene-phenotype relationships, reported a study published in 2004 in which the ACE1 D-allele was considered a 
genetic predisposition favoring the progression from pneumonia to SARS in Vietnamese patients [56]. Two years before, susceptibility and outcome in ARDS patients were associated with the ACE I/D polymorphism [58], although following publications did not confirm this issue [59-61]. The recent SARS-CoV-2 pandemic fired-up again the interest on ACE1 I/D polymorphism, and despite the several recent investigations, definite results are still lacking [2,29-32], though a recent paper ascribed an ACE1 I/I-genotype inverse relation to SARS-CoV-2 related mortality, disclosing exciting correspondences between geographic ACE1 genotype distribution and COVID-19 morbidity and/or mortality [28] (Table 1). Overall, a correlation between ACE1 I/D genotypes in previous SARS and in SARS-CoV-2 morbidity and mortality exists, ascribing to the D/D genotype the worst prognosis. The European populations have higher ACE1 D/D genotype and mortality rates due to COVID-19 than Asians. Accordingly, there is an increasing trend from northern Europe to southern Europe of ACE1 D/D genotype, and geographically moving eastward from Europe to Asia, the ACE1 D/D genotype rate decreases [57,62]. This coincides with the geographical migration of the modern Homo sapiens out of Africa and with the associated increasing gradient of the ACE1 I/I genotype. In this scenario, Yamamoto et al. recently reported detailed information on ACE1 I/I genotype rates among European, Middle Eastern, South Asian and East Asian countries, merging data from the Center for Systems Science and Engineering at Johns Hopkins University detailing ACE1 I/I genotype frequencies, number of affected cases/population and number of deaths [28].

Table 1. Relevant publications dealing with ACE1 I/D polymorphism in COVID-19.

\begin{tabular}{|c|c|c|c|}
\hline Type of Manuscript & $\begin{array}{l}\text { Geographical Regions } \\
\text { (Ethnicity) }\end{array}$ & $\begin{array}{l}\text { Association with SARS-CoV-2 Infection and/or } \\
\text { COVID-19 Clinical Phenotype }\end{array}$ & Ref. \\
\hline $\begin{array}{l}\text { Epidemiological } \\
\text { investigation }\end{array}$ & Asian continent & $\begin{array}{l}\text { Positive correlation of D-allele with infection and } \\
\text { SARS-CoV-2 mortality rates } \\
\text { No significant correlation between D-allele with } \\
\text { patient recovery rate }\end{array}$ & [63] \\
\hline $\begin{array}{l}\text { Ecological Study } \\
\text { (meta-analysis) }\end{array}$ & $\begin{array}{l}\text { Worldwide } \\
\text { (50 high income } \\
\text { countries) }\end{array}$ & $\begin{array}{l}\text { Positive association of D-allele with cumulative } \\
\text { incidence and death rate } \\
\text { Possible biological plausibility for the association }\end{array}$ & [64] \\
\hline Hypothesis paper & $\begin{array}{l}\text { Central Europe versus } \\
\text { East Asia }\end{array}$ & $\begin{array}{l}\text { ACE1/ACE2 imbalance predicts DD-genotype and } \\
\text { D-allele have higher disease prevalence and severity } \\
\text { in COVID-19 }\end{array}$ & [65] \\
\hline Meta-Analysis & $\begin{array}{c}\text { Worldwide } \\
\text { (30 different countries) }\end{array}$ & $\begin{array}{l}\text { Positive correlation between higher I/D allele } \\
\text { frequency ratio and increased disease recovery rate } \\
\text { No significant difference in case death rate }\end{array}$ & [26] \\
\hline $\begin{array}{l}\text { Epidemiological } \\
\text { investigation }\end{array}$ & $\begin{array}{c}\text { Europe } \\
\text { (25 different countries) }\end{array}$ & $\begin{array}{l}\text { Inverse correlation between D-allele frequency with } \\
\text { log-transformed prevalence of COVID-19 infections } \\
\text { and mortality }\end{array}$ & [32] \\
\hline $\begin{array}{l}\text { Epidemiological } \\
\text { investigation }\end{array}$ & $\begin{array}{l}\text { European, North-African } \\
\text { and Middle East } \\
\text { countries } \\
(33 \text { countries })\end{array}$ & $\begin{array}{l}\text { Negative correlation between log-transformed } \\
\text { COVID-19 prevalence and associated mortality with } \\
\text { D-allele frequency }\end{array}$ & [31] \\
\hline $\begin{array}{l}\text { Letter to the Editor } \\
\text { (Counterpoint) }\end{array}$ & - & $\begin{array}{l}\text { Necessity of considering well-defined geographical } \\
\text { spaces to score a polymorphism in a multivariate } \\
\text { analysis evaluating its influence on SARS-CoV-2 } \\
\text { related infection risk and COVID-19 mortality risk }\end{array}$ & [29] \\
\hline $\begin{array}{l}\text { Epidemiological } \\
\text { investigation }\end{array}$ & $\begin{array}{l}\text { European, Middle } \\
\text { Eastern, South Asian and } \\
\text { East Asian countries }\end{array}$ & $\begin{array}{l}\text { Negative correlation between II-genotype frequency } \\
\text { and SARS-CoV-2 infection rate and number of } \\
\text { COVID-19 deaths } \\
\text { Increasing trend of II-genotype frequency from } \\
\text { European to Asian countries }\end{array}$ & [28] \\
\hline Hypothesis paper & - & $\begin{array}{l}\text { Sex differences in I/D allele distribution suggest a } \\
\text { higher chance of ACE1/ACE2 imbalance among } \\
\text { males during ACE2 receptor suppression due to } \\
\text { SARS-CoV-2 infection }\end{array}$ & [2] \\
\hline
\end{tabular}


ACE2 gene maps on chromosome $\mathrm{X}$ (locus Xp22.22) comprise 18 exons, accounting for a full-length gene of approximately $41 \mathrm{~kb}$, coding for a gene product of 805 aa responsible for the conversion of Ang-II to Ang 1-7. One of the ACE2 isoforms contains an extra exon at the $5^{\prime}$-end (Genbank, NT011757), though no differences in the number of the unique active site of the enzyme there exists. ACE2 and ACE1 share $42 \%$ homology in the amino acid sequence of the catalytic domain and have similar exon/intron organization, indicating a common ancestor origin. Several gene variants have been listed in the ACE2 gene [66] also among those amino acids within domains crucial for ACE2 molecule stability and SARS-CoV-2 entry, hypothesizing sex-differences in receptor-virus affinities [2,67]. In addition, no direct evidence supported the existence of genetically resistant ACE2 mutants against SARS-CoV-2 in different populations [68], although a recent analysis on ACE2 genetic variability highlighted the possibility to link single nucleotide variations to the risk of COVID-19 neurological complications [69]. Rather, single-cell RNA-seq analysis reported that African-American and Whites have a lower ACE2 expression cell ratio than Asians, and data accounting for gene variant distribution and allele frequency from East Asian populations yielded higher allele frequencies in variants associated with higher ACE2 expression, suggesting different individual susceptibility to SARS-CoV-2 within different populations $[68,70,71]$.

Among the most relevant polymorphisms influencing ACE2 activity and levels, attention has been paid to the transition G8790A (rs2285666), with the G/G genotype characterized by about $50 \%$ expression reduction compared to A/A genotype [72,73]. Interestingly, this SNP is highly represented within Chinese populations (China-MAP, 0.556 and Han-Chinese-South, 0.557), which have the highest allele frequency among those variants within the $A C E 2$ gene compared to others populations (e.g., Ad Mixed American, 0.336; African, 0.2114; European, 0.235). This corroborates the hypothesis that, as for the ACE1 gene, selected haplotypes linked to high ACE2 expression might influence SARS-Cov-2 CFR among different populations according to the protective role of ACE2 against multifactorial thrombosis [74,75], endothelial dysfunction [76] and severe acute lung failure [2,77].

Given the position of G8790A at the beginning of ACE2 intron $3($ c. $439+4 \mathrm{G}>\mathrm{A})$, alternative splicing mechanisms affect gene expression [78,79], with two additional intronic SNPs (rs1978124 and rs714205) in strong linkage disequilibrium with rs2285666 [80,81]. It should be taken into account that X-linked genes (i.e., ACE2) in presence of detrimental gene variants affecting product activity, as for the one associated with $8790 \mathrm{G}$-allele, cannot compensate male-carriers with the normal counterpart 8790 A-allele, with males being hemizygotes and females potentially heterozygotes. This is of particular interest in complex diseases with a strong sex-gap in prognosis, as for SARS-CoV-2 infection [2].

ACE2 G8790A has been explored in the past in association with hypertension in studies mainly performed among China populations observing a higher frequency of the $8790 \mathrm{~A}$-allele in China [81], though several issues still remain inconclusive [82,83]. More recently, five additional SNPs (rs1514283, rs4646155, rs4646176, rs2285666 and rs879922) in the ACE2 gene have been reported to be associated with essential hypertension in women of the Chinese Han population during the COVID-19 outbreak [84], though the association with hypertension exhibited high heterogeneity and varies with geographical, ethnic and gender also among the Chinese population [85]. In particular, one of these SNPs (rs2285666; $\mathrm{C} / \mathrm{T}$ ) is characterized by a significant different allele frequency among the Italian population with respect to the worldwide population, being strongly underrepresented among Italians $(C=209 ; T=35)$ with respect to both East and South Asians (EAS: $\mathrm{C}=354 ; \mathrm{T}=410$ and SAS: $\mathrm{C}=374 ; \mathrm{T}=344$ ) and less if compared to Americans $(C=458 ; T=215)$ or to the rest of the European populations $(C=345$; $\mathrm{T}=111$ ) [69]. The rs2285666 variant is located in the splice site region of ACE2 gene, and although the Human Splicing Finder analysis did not predict significant splicing alterations, it was classified as a significant eQTL in several brain tissues [69].

$A C E 1$ and $A C E 2$ are key genes in maintaining RAS balance and having significant differences in the worldwide distribution of their genetic variants affecting the respective activities, they should be investigated in combination [2,72,86,87]. A recent report on an ACE1 I/D and ACE2 G8790A combined analysis hypothesized that high ACE1 activity (i.e., ACE1 D/D-genotype) together with low ACE2 activity (i.e., ACE2 G/G-females or hemizygous G-males) could be considered a high-risk 
combination for hypertension in presence of cardiovascular risk factors, old age, dyslipidemia and diabetes [72]. The hypothesized increased genetic susceptibility to unbalance ACE1/ACE2 is not a remote possibility because of the high frequency of both variants particularly observed in some populations where SARS-CoV-2 CFR was higher. In that paper, the assumed "at risk combination" (i.e., ACE1 D-allele plus ACE2 G-allele) was 13.8\% (DD/GG) and 23.0\% (DD/GG+GA) among hypertensive females (healthy controls showed $4.9 \%$ and $9.9 \%$, respectively) according to a dominant model or a recessive model, respectively, and 56.7\% (DD/ID plus G-allele) among hypertensive males. Of interest, the genetic counterpart assumed as "protective combination" (i.e., II/AA homozygous female cases and II/A- hemizygous male cases) was $2.3 \%$ and $10 \%$, respectively, accounting for a 10-fold and 5.7-fold difference [72]. Moreover, previous Genome-Wide Association Studies (GWAS) aimed at identifying novel quantitative trait loci regulating ACE1 activity and ACEi pharmacogenetics, recognized new variants in the ACE1 gene (rs4343) and in the $A B O$-blood group locus (rs495828 and rs8176746) [88], providing an explanation for the correlation of the ABO-locus/ACE1-ACE2 mutual levels/RAS-unbalancing/severe COVID-19. This is in line with the recent GWAS that associates locus 3p21.31 (rs11385942), comprising the solute carrier SLC6A20 (Na+ and Cl- coupled transporter family), and locus 9q34.2 (rs657152) that is coincident with the ABO-blood group (rs8176747, rs41302905, rs8176719) to Italian and Spanish severe COVID-19 patients with respiratory failure [89]. Of note, the lead variant (rs11385942) is located in an intergenic region spanning several genes (SLC6A20, LZTFL1, CCR9, FYCO1, CXCR6, XCR1); at least two of them (LZTFL1, CCR9) are closely located and the risk allele GA of rs11385942 is associated with increased expression of SLC6A20 and LZTFL1 in human lung cells. Moreover, authors supported the role of $A B O$ in COVID-19 prognosis, considering the presence of neutralizing antibodies against protein-linked $\mathrm{N}$-glycans in the O-group compared to non-O blood groups $[89,90]$ as well as the well-known link existing between the $A B O-l o c u s$ and coagulation von Willebrand factor gene expression (i.e., VWF; locus 12p13.31), evoking thrombosis and coagulation disturbances as one of the main mechanisms involved. The VWF protein is the carrier of coagulation Factor VIII and high levels of VWF-FVIII complex are a well-known prothrombotic risk factor not only for intrinsic procoagulant properties but also for affecting the natural anticoagulant effects. In terms of biological mechanistic insights, pulmonary endothelial-cells of non-O blood groups are associated with higher VWF protein compared to O-group, accounting for the role that the GWAS ascribed to the ABO-locus in COVID-19 [91-93].

Though strongly plausible, we suggest to also consider the $A B O$ and SLC6A20 effects on the ACE1/ACE2 mutual levels, on the RAS pathway and on the salt/water homeostasis [2,94-96]. The ABO-locus also influences the ACEi response [72,94-96] and has been found to reduce previous SARS-CoV infection in both pandemic spreading and individual susceptibility, hypothesizing that the O-blood group was at lower risk of infection by natural anti-A and anti-B antibody protection against viruses [97]. Of note, there is a significant sex difference in ACE1 activity/levels, with females showing lower levels compared to males in both healthy and pathological conditions [2,98]. In addition, the ACE1 I-allele seems overrepresented among females that could be protected [2] and the D-allele expresses higher levels among males, suggesting in them a higher chance of ACE1/ACE2 imbalance during SARS-CoV-2 infection [1,2,99].

Finally, the RAS pathway can also be affected by other genes, including the ACE2-shedder ADAM17, which pushes down the ACE2/Ang1-7/Mas axis, SRY (Y-chromosome) and SOX3 (X-chromosome), which upregulate AGT and downregulate ACE2, AT2, MAS. Conversely, SRY and SOX3 have an opposite effect on the REN promoter [100,101] (Table 2). Altogether, these data ascribe to genes in the RAS pathway a crucial role in COVID-19 prognosis. 
Table 2. Main genes directly or indirectly involved in the RAS pathway and in salt/water homeostasis.

\begin{tabular}{|c|c|c|}
\hline Gene & Name & Locus \\
\hline$A B O$ & $\begin{array}{c}\alpha \\
\text { 1-3-N-acetylgalactosaminyltransferase } \\
\alpha 1-3-\text { galactosyltransferase }\end{array}$ & $9 \mathrm{q} 34.2$ \\
\hline ACE1 & Angiotensin I converting enzyme 1 & $17 q 23.3$ \\
\hline$A C E 2$ & Angiotensin I converting enzyme 2 & Xp22.2 \\
\hline ADAM17 & $\begin{array}{c}\text { Metallopeptidase domain } 17 \\
\text { TNF } \alpha \text {-converting enzyme (TACE) }\end{array}$ & $2 \mathrm{p} 25.1$ \\
\hline$A G T$ & Angiotensinogen & $1 \mathrm{q} 42.2$ \\
\hline AGTR1 (AT1) & Angiotensin II receptor type 1 & $3 q 24$ \\
\hline AGTR2 (AT2) & Angiotensin II receptor type 2 & $\mathrm{Xq} 23$ \\
\hline REN & Renin & $1 \mathrm{q} 32.1$ \\
\hline MAS1 & MAS1 proto-oncogene & $6 \mathrm{q} 25.3$ \\
\hline SLC6A20 & Solute Carrier Family 6 Member 20 & $3 p 21.31$ \\
\hline SOX3 & SRY-box transcription factor 3 & Xq27.1 \\
\hline$S R Y$ & Sex determining region $\mathrm{Y}$ & Yp11.2 \\
\hline
\end{tabular}

\section{ACEi and ARBs}

Rebalancing RAS pathway plays a key role in the management of several pathological conditions including hypertension, cardiovascular disease, heart failure, diabetes and chronic kidney disease. Four groups of classic RAS antagonists act by targeting the Ang-I/Ang-II/AT1-receptor-axis, though new classes of pharmacological compounds targeting newly discovered RAS constituents have been developed [102,103].

The classical drugs interfering with RAS include the ACEi and ARBs directly or indirectly targeting Ang-II, the renin inhibitors targeting both Ang-I and Ang-II and the mineralocorticoid receptor antagonists targeting aldosterone, though many other RAS peptides (Ang 1-7, Ang 1-9, Ang-III, Ang-IV) play significant roles (Figure 1) [102,103].

ACEi activity is based on the competitive inhibition of ACE1 leading to the block of the Ang-I-to-Ang-II transformation and of Bradykinin degradation, a potent peptide with vasodilator activity promoting several effects including prostacyclin and nitric oxide release. Although different ACEi classes show differences in pharmacokinetic and ACE1-binding affinity, the overall effect is ascribable to Ang-II decrease, associated with aldosterone and vasopressin reduction, Ang-I and Bradykinin increase, without effects on Ang-II-receptors or on other RAS peptide actions. Escaping mechanisms associated with prolonged ACEi treatment, aiming at restoring Ang-II levels, have been recognized. The available drugs include Captopril, used in clinical practice since the 1980s, Benazepril, Enalapril, Fosinopril and many others commercially released over time [104].

ARBs have been developed to complete ACEi action and compensate/counteract their limitations and side effects. They block AT1R with high affinity and with a selectivity of about 10000 -folds higher for AT1R compared to AT2R. Abrogation of AT1R pathway overall leads to vasodilatation and decrease on peripheral resistance that might be also due to a constant AT2R stimulation, though this relationship is still unclear [105]. ARBs chemical structure differs in the several compounds leading to differences in receptor binding kinetics and in the ability to suppress adrenal aldosterone. The available ARBs include Losartan, developed in the 1990s, Candesartan, reported as the most AT1R selective antagonist, and other compounds such as Eprosartan, Irbesartan, Telmisartan, Valsartan and Olmesartan, showing different clinical and pharmacological features [106]. The concern of continuing or dismissing ACEi and ARBs treatments in COVID-19 patients has become of great relevance since the discovery that SARS-CoV-2 uses ACE2 as main receptor to enter human cells. A recent metanalysis reported 
that ACEi/ARBs did not worsen COVID-19 severity in hypertensive patients, suggesting a possible underestimation of the protective effects of RAS inhibitors in COVID-19, cautiously leaving open the hypothesis that there might be potential benefits of using ACEi/ARBs in COVID-19 management [107]. Pharmacogenetic investigations in line with personalized and precision medicine approach will shed light on this crucial point, also helping drug repositioning against SARS-CoV-2.

\section{Conclusions}

The observation that severe COVID-19 patients who develop ARDS are more likely to have a history of hypertension, diabetes, cardiovascular disease and RAS inhibitor treatment highlighted the role of RAS genes and raised pharmacogenetics concerns on the safety of such pharmacological approach. However, the impressive amount of literature on this topic published during the first few months of 2020 did not completely account for several potential confounding factors such as comorbidities, concomitant treatments and baseline pulmonary efficiency, as well as sex, age and ethnicity. Sex, age and hormones are of particular relevance as they dramatically affect cardiovascular disease establishment and prognosis, influencing in turn COVID-19 severity [108]. Moreover, individual genetic backgrounds have been scarcely considered. Host genetics undoubtedly has a role in SARS-CoV-2 pathophysiology, influencing both individual susceptibility to infection and disease progression [2,33]. Although no genetically resistant ACE2 mutant receptors against SARS-CoV-2 have been recognized in different populations, a wide spectrum in symptoms, disease severity and CFR has been described in different countries, and ACE2 gene has been considered the "first genetic gateway" involved in infection, severity and outcome [109]. Around the world, various countries differently contrasted the SARS-CoV-2 pandemic according to their health care systems. Nevertheless, it has been reported that Europe experienced the highest CFR (9.6\%), followed by North America $(5.9 \%)$ and Asia, this last showing the lowest value $(3.5 \%)$ despite the pandemic having spread from China [27,110,111]. Interestingly, place- and age-adjusted CFR evaluations in USA, comparing Blacks, Whites, Hispanics and Asians, ascribed to Blacks the highest CFR in crude-, place-, ageand age/place-adjusted analyses, suggesting gene-environment interactions and ethnic disparities, having compared different ethnicities living in the same country [112,113]. Nevertheless, the apparent difference in disease fatalities between countries, central Europe and East Asia, or in the same country among different ethnicities as reported in US, suggests different possible explanations should be taken into account. Among these, demographics, social/cultural behaviors, local hygienic aspects, delay in outbreaks establishment and low virus-testing capacity are variables that may significantly account for the observed gaps in controlling the pandemic, as well as the availability of artificial respiratory and specialized staff [65]. In addition, multiple viral infections and the involvement of associated immuno-virological factors or potential coronavirus resistance gene mutations occurring among East Asians as a result of long-term co-evolution of the virus and host cannot be excluded [65]. Finally, the existence of health inequities among minority populations unmasked how the pandemic greatly affects the most socially and economically disadvantaged people/gender but paradoxically, also countries with universal health coverage are not able to completely protect its inhabitants against high CFR due to COVID-19 pandemic [2,110,112-114].

Accordingly, whether or not lung injury will establish after virus infection may depend on several inherited, acquired and social/political concomitant factors. Genetically determined ACE1 and ACE2 levels, by modulating the dynamic of angiotensin peptides, contribute in maintaining RAS balance and organ homeostasis. On the other hand, a pharmacogenetically determined response to RAS inhibitors contributes to overall drug therapeutic efficacy and/or negative side effects establishment.

To further expand our two recently hypothesized genetic mechanisms [2] based on the two recently-suggested pharmacological mechanisms tuning RAS over-activation during virus infection [25], we have here described two possible opposite genetic scenarios. In the first hypothesis, the resulting unbalance may be weakened by protective inherited mechanisms in both ACE1 and ACE2 genes, considering "gain of function" gene variants in ACE2 gene (i.e., rs2285666) and/or "loss of function" 
gene variants in ACE1 gene (i.e., rs4646994). This hypothesizes the existence of inherited protective predispositions to counteract ACE1/ACE2 unbalance caused by virus infection. In the second hypothesis, the opposite haplotype condition might indeed exacerbate RAS unbalance due to SARS-CoV-2 infection and be considered a high-risk setting for organ dysfunction and ARDS. A schematic representation of the complementary hypothesized mechanisms is shown in Figure 2. Likewise, over-activated RAS pathway is efficaciously pharmacologically rebalanced by ACEi and ARBs and several pharmacogenetics studies focused on this issue demonstrated how the same drug may lead to different efficacy and safety in different populations, ascribing this to the different geographic distribution of the aforementioned gene variants $[72,115,116]$ recalling the "thrifty genotype hypothesis" [57]. A combination of other particular protective- or at risk-inherited predispositions could also contribute to the unexplained wide range of the clinical manifestations observed among SARS-CoV-2 infected patients (i.e., asymptomatic, paucisymptomatic and severe patients) and help to further improve drug repositioning.

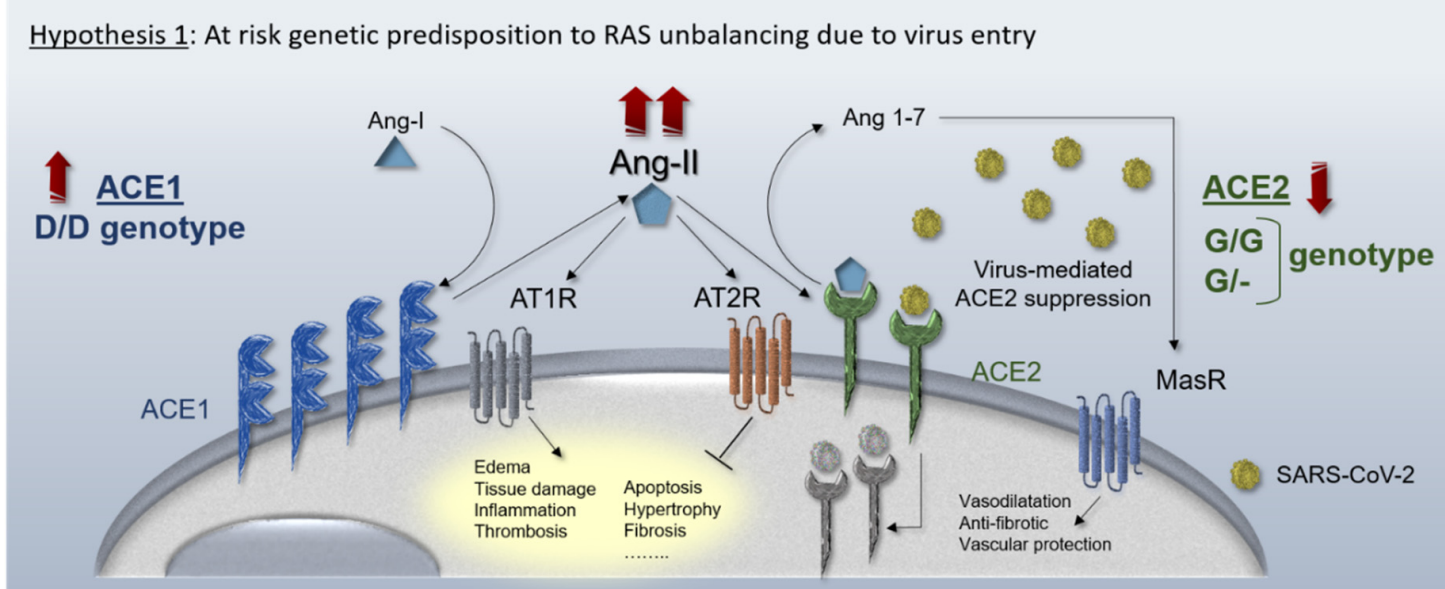

Hypothesis 2: Protective genetic predisposition against RAS unbalancing due to virus entry

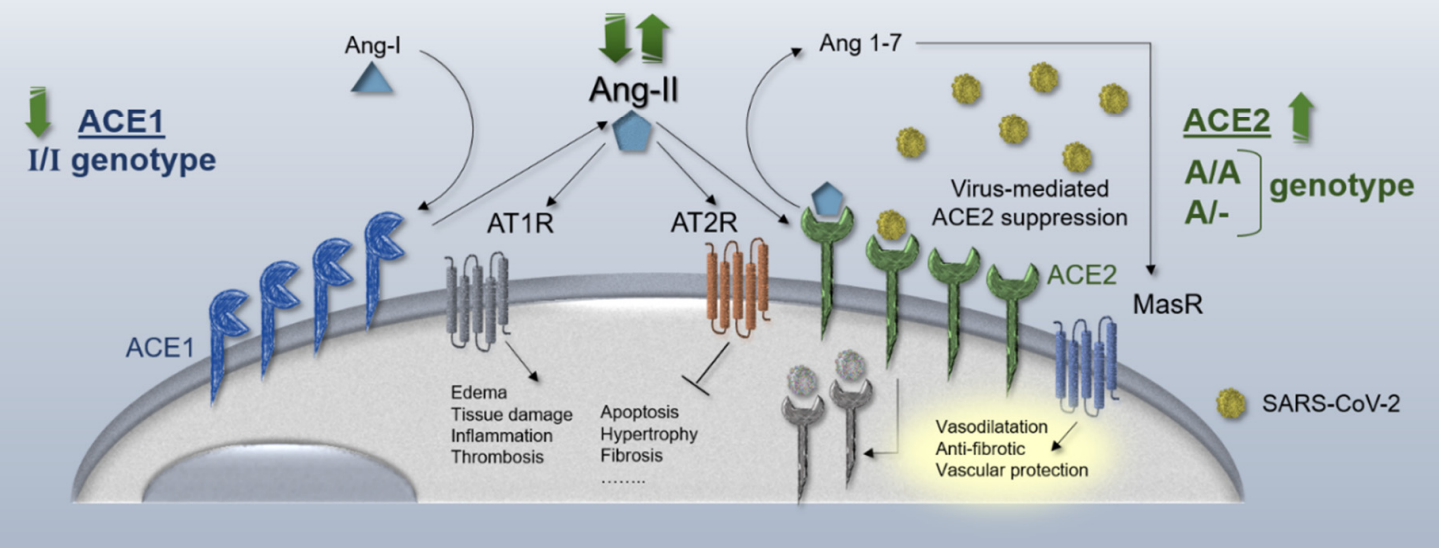

Figure 2. Hypothesized mechanisms of different genetic haplotypes in ACE1 and ACE2 genes in the RAS pathway. Upper panel, the ACE2 downregulation due to virus entry is exacerbated by "loss of function" ACE2 8790 G/G genotype (homozygous G/G females and hemizygous G/- males). The coexistence of ACE1 upregulation due to "gain of function" D/D genotype leads on unrestrained RAS deregulation and ARDS establishment. Lower panel, the ACE2 downregulation due to virus entry is weakened by "gain of function" ACE2 8790 A/A genotype (homozygous A/A females and hemizygous A/- males). The coexistence of ACE1 downregulation due to "loss of function" I/I genotype counteracts RAS unbalancing avoiding ARDS establishment. 
Specific transmission dynamics, in accordance with spatial epidemiology, strongly comply with individual and population genetic landscapes, particularly for complex models of polygenic diseases in which gene-environment interactions have a role $[74,75,117,118]$. Then, urgent efforts are needed to develop host genetics and genomics networks accounting for ethnic/geographical variations mainly involving RAS, HLA, CKs, TLR, coagulation and complement pathways as recently suggested [109] displaying distinct geographical and population distributions influencing prognosis and susceptibility to several viral infections dramatically useful to prevent or counteract possible SARS-CoV-2 second waves. Our hypotheses in favor of RAS pathway over-activation as one of the main causes in determining COVID-19 susceptibility and severity, is completely in line with the recently GWAS identified associations of $A B O$ and SLC6A20 loci [89] being crucial modifiers of Ang-II local levels and water/salt reabsorption [2,95,119-121].

Finally, while waiting for further results from large GWAS and epidemiological studies among different geographic populations, investigations on other target candidate genes affecting crucial pathways should also be performed. Accordingly, extreme-clinical-phenotype-comparisons or extreme-genotype-comparisons within infected SARS-CoV-2 patients will reveal how genetically determined pathways (un)balance may influence COVID-19 progression, treatment response and prognosis useful to early identify individuals at high risk of poor prognosis, improving complication prevention and appropriate drug selection and repositioning.

Author Contributions: D.G. and V.T.: conceptualization, writing, revising and figure preparation. All authors have read and agreed to the published version of the manuscript.

Funding: This research was funded by Local Research grants from University of Ferrara, Italy (FIR and FAR to D.G. and V.T.).

Conflicts of Interest: The authors declare no conflict of interest.

\section{References}

1. Hoffmann, M.; Kleine-Weber, H.; Schroeder, S.; Kruger, N.; Herrler, T.; Erichsen, S.; Schiergens, T.S.; Herrler, G.; Wu, N.H.; Nitsche, A.; et al. SARS-CoV-2 Cell Entry Depends on ACE2 and TMPRSS2 and Is Blocked by a Clinically Proven Protease Inhibitor. Cell 2020, 181, 271-280.e8. [CrossRef] [PubMed]

2. Gemmati, D.; Bramanti, B.; Serino, M.L.; Secchiero, P.; Zauli, G.; Tisato, V. COVID-19 and Individual Genetic Susceptibility/Receptivity: Role of ACE1/ACE2 Genes, Immunity, Inflammation and Coagulation. Might the Double X-chromosome in Females Be Protective against SARS-CoV-2 Compared to the Single X-Chromosome in Males? Int. J. Mol. Sci. 2020, 21, 3474. [CrossRef] [PubMed]

3. Sukumaran, V.; Veeraveedu, P.T.; Gurusamy, N.; Lakshmanan, A.P.; Yamaguchi, K.; Ma, M.; Suzuki, K.; Nagata, M.; Takagi, R.; Kodama, M.; et al. Olmesartan attenuates the development of heart failure after experimental autoimmune myocarditis in rats through the modulation of ANG 1-7 mas receptor. Mol. Cell Endocrinol. 2012, 351, 208-219. [CrossRef] [PubMed]

4. Ferrario, C.M.; Jessup, J.; Chappell, M.C.; Averill, D.B.; Brosnihan, K.B.; Tallant, E.A.; Diz, D.I.; Gallagher, P.E. Effect of angiotensin-converting enzyme inhibition and angiotensin II receptor blockers on cardiac angiotensin-converting enzyme 2. Circulation 2005, 111, 2605-2610. [CrossRef]

5. Sukumaran, V.; Veeraveedu, P.T.; Lakshmanan, A.P.; Gurusamy, N.; Yamaguchi, K.; Ma, M.; Suzuki, K.; Kodama, M.; Watanabe, K. Olmesartan medoxomil treatment potently improves cardiac myosin-induced dilated cardiomyopathy via the modulation of ACE-2 and ANG 1-7 mas receptor. Free Radic Res. 2012, 46, 850-860. [CrossRef]

6. Soler, M.J.; Barrios, C.; Oliva, R.; Batlle, D. Pharmacologic modulation of ACE2 expression. Curr. Hypertens. Rep. 2008, 10, 410-414. [CrossRef]

7. Campbell, D.J.; Zeitz, C.J.; Esler, M.D.; Horowitz, J.D. Evidence against a major role for angiotensin converting enzyme-related carboxypeptidase (ACE2) in angiotensin peptide metabolism in the human coronary circulation. J. Hypertens. 2004, 22, 1971-1976. [CrossRef] 
8. Furuhashi, M.; Moniwa, N.; Mita, T.; Fuseya, T.; Ishimura, S.; Ohno, K.; Shibata, S.; Tanaka, M.; Watanabe, Y.; Akasaka, H.; et al. Urinary angiotensin-converting enzyme 2 in hypertensive patients may be increased by olmesartan, an angiotensin II receptor blocker. Am. J. Hypertens. 2015, 28, 15-21. [CrossRef]

9. Epelman, S.; Shrestha, K.; Troughton, R.W.; Francis, G.S.; Sen, S.; Klein, A.L.; Tang, W.H. Soluble angiotensin-converting enzyme 2 in human heart failure: Relation with myocardial function and clinical outcomes. J. Card. Fail. 2009, 15, 565-571. [CrossRef]

10. Esler, M.; Esler, D. Can angiotensin receptor-blocking drugs perhaps be harmful in the COVID-19 pandemic? J. Hypertens. 2020, 38, 781-782. [CrossRef]

11. Fang, L.; Karakiulakis, G.; Roth, M. Are patients with hypertension and diabetes mellitus at increased risk for COVID-19 infection? Lancet Respir. Med. 2020, 8, e21. [CrossRef]

12. Su, L.; Ma, X.; Yu, H.; Zhang, Z.; Bian, P.; Han, Y.; Sun, J.; Liu, Y.; Yang, C.; Geng, J.; et al. The different clinical characteristics of corona virus disease cases between children and their families in China-The character of children with COVID-19. Emerg. Microbes Infect. 2020, 9, 707-713. [CrossRef] [PubMed]

13. Ng, P.C.; Lam, C.W.; Li, A.M.; Wong, C.K.; Cheng, F.W.; Leung, T.F.; Hon, E.K.; Chan, I.H.; Li, C.K.; Fung, K.S.; et al. Inflammatory cytokine profile in children with severe acute respiratory syndrome. Pediatrics 2004, 113, e7-e14. [CrossRef] [PubMed]

14. Karlberg, J.; Chong, D.S.; Lai, W.Y. Do men have a higher case fatality rate of severe acute respiratory syndrome than women do? Am. J. Epidemiol. 2004, 159, 229-231. [CrossRef]

15. Gausman, J.; Langer, A. Sex and Gender Disparities in the COVID-19 Pandemic. J. Womens Health (Larchmt) 2020, 29, 465-466. [CrossRef]

16. Rodriguez-Puertas, R. ACE2 activators for the treatment of COVID 19 patients. J. Med. Virol. 2020. [CrossRef]

17. Haschke, M.; Schuster, M.; Poglitsch, M.; Loibner, H.; Salzberg, M.; Bruggisser, M.; Penninger, J.; Krahenbuhl, S. Pharmacokinetics and pharmacodynamics of recombinant human angiotensin-converting enzyme 2 in healthy human subjects. Clin. Pharmacokinet. 2013, 52, 783-792. [CrossRef]

18. Zhang, H.; Baker, A. Recombinant human ACE2: Acing out angiotensin II in ARDS therapy. Crit. Care 2017, 21, 305. [CrossRef]

19. Khan, A.; Benthin, C.; Zeno, B.; Albertson, T.E.; Boyd, J.; Christie, J.D.; Hall, R.; Poirier, G.; Ronco, J.J.; Tidswell, M.; et al. A pilot clinical trial of recombinant human angiotensin-converting enzyme 2 in acute respiratory distress syndrome. Crit. Care 2017, 21, 234. [CrossRef]

20. Mancia, G.; Rea, F.; Ludergnani, M.; Apolone, G.; Corrao, G. Renin-Angiotensin-Aldosterone System Blockers and the Risk of Covid-19. N. Engl. J. Med. 2020, 382, 2431-2440. [CrossRef]

21. Reynolds, H.R.; Adhikari, S.; Pulgarin, C.; Troxel, A.B.; Iturrate, E.; Johnson, S.B.; Hausvater, A.; Newman, J.D.; Berger, J.S.; Bangalore, S.; et al. Renin-Angiotensin-Aldosterone System Inhibitors and Risk of Covid-19. N. Engl. J. Med. 2020, 382, 2441-2448. [CrossRef]

22. Mehra, M.R.; Desai, S.S.; Kuy, S.; Henry, T.D.; Patel, A.N. Cardiovascular Disease, Drug Therapy, and Mortality in Covid-19. N. Engl. J. Med. 2020, 382, e102. [CrossRef] [PubMed]

23. Brojakowska, A.; Narula, J.; Shimony, R.; Bander, J. Clinical Implications of SARS-CoV-2 Interaction With Renin Angiotensin System: JACC Review Topic of the Week. J. Am. Coll. Cardiol. 2020, 75, 3085-3095. [CrossRef] [PubMed]

24. Vaduganathan, M.; Vardeny, O.; Michel, T.; McMurray, J.J.V.; Pfeffer, M.A.; Solomon, S.D. Renin-Angiotensin-Aldosterone System Inhibitors in Patients with Covid-19. N. Engl. J. Med. 2020, 382, 1653-1659. [CrossRef] [PubMed]

25. South, A.M.; Tomlinson, L.; Edmonston, D.; Hiremath, S.; Sparks, M.A. Controversies of renin-angiotensin system inhibition during the COVID-19 pandemic. Nat. Rev. Nephrol. 2020, 16, 305-307. [CrossRef] [PubMed]

26. Hatami, N.; Ahi, S.; Sadeghinikoo, A.; Foroughian, M.; Javdani, F.; Kalani, N.; Fereydoni, M.; Keshavarz, P.; Hosseini, A. Worldwide ACE (I/D) polymorphism may affect COVID-19 recovery rate: An ecological meta-regression. Endocrine 2020, 68, 479-484. [CrossRef]

27. Gupta, R.; Misra, A. COVID19 in South Asians/Asian Indians: Heterogeneity of data and implications for pathophysiology and research. Diabetes Res. Clin. Pract. 2020, 165, 108267. [CrossRef]

28. Yamamoto, N.; Ariumi, Y.; Nishida, N.; Yamamoto, R.; Bauer, G.; Gojobori, T.; Shimotohno, K.; Mizokami, M. SARS-CoV-2 infections and COVID-19 mortalities strongly correlate with ACE1 I/D genotype. Gene 2020, 758, 144944. [CrossRef] 
29. Delanghe, J.R.; Speeckaert, M.M.; De Buyzere, M.L. ACE Ins/Del genetic polymorphism and epidemiological findings in COVID-19. Clin. Chem. Lab. Med. 2020, 58, 1129-1130. [CrossRef]

30. Saadat, M. No significant correlation between ACE Ins/Del genetic polymorphism and COVID-19 infection. Clin. Chem. Lab. Med. 2020, 58, 1127-1128. [CrossRef]

31. Delanghe, J.R.; Speeckaert, M.M.; De Buyzere, M.L. COVID-19 infections are also affected by human ACE1 D/I polymorphism. Clin. Chem. Lab. Med. 2020, 58, 1125-1126. [CrossRef] [PubMed]

32. Delanghe, J.R.; Speeckaert, M.M.; De Buyzere, M.L. The host's angiotensin-converting enzyme polymorphism may explain epidemiological findings in COVID-19 infections. Clin. Chim. Acta 2020, 505, 192-193. [CrossRef] [PubMed]

33. Asselta, R.; Paraboschi, E.M.; Mantovani, A.; Duga, S. ACE2 and TMPRSS2 variants and expression as candidates to sex and country differences in COVID-19 severity in Italy. Aging (Albany N.Y.) 2020, 12, 10087-10098. [CrossRef]

34. Qu, G.; Li, X.; Hu, L.; Jiang, G. An Imperative Need for Research on the Role of Environmental Factors in Transmission of Novel Coronavirus (COVID-19). Environ. Sci. Technol. 2020, 54, 3730-3732. [CrossRef] [PubMed]

35. Harada, K.H.; Harada Sassa, M.; Yamamoto, N. Letter to the Editor on "An Imperative Need for Research on the Role of Environmental Factors in Transmission of Novel Coronavirus (COVID-19)", Back to Basics. Environ. Sci. Technol. 2020, 54, 7738-7739. [CrossRef]

36. Ehlers, M.R.; Riordan, J.F. Angiotensin-converting enzyme: New concepts concerning its biological role. Biochemistry 1989, 28, 5311-5318. [CrossRef]

37. Gonzalez-Villalobos, R.A.; Shen, X.Z.; Bernstein, E.A.; Janjulia, T.; Taylor, B.; Giani, J.F.; Blackwell, W.L.; Shah, K.H.; Shi, P.D.; Fuchs, S.; et al. Rediscovering ACE: Novel insights into the many roles of the angiotensin-converting enzyme. J. Mol. Med. (Berl.) 2013, 91, 1143-1154. [CrossRef]

38. Hamming, I.; Timens, W.; Bulthuis, M.L.; Lely, A.T.; Navis, G.; van Goor, H. Tissue distribution of ACE2 protein, the functional receptor for SARS coronavirus. A first step in understanding SARS pathogenesis. J. Pathol. 2004, 203, 631-637. [CrossRef]

39. Li, X.; Rayford, H.; Uhal, B.D. Essential roles for angiotensin receptor AT1a in bleomycin-induced apoptosis and lung fibrosis in mice. Am. J. Pathol. 2003, 163, 2523-2530. [CrossRef]

40. Uhal, B.D.; Dang, M.T.; Li, X.; Abdul-Hafez, A. Angiotensinogen gene transcription in pulmonary fibrosis. Int. J. Pept. 2012, 2012, 875910. [CrossRef]

41. He, X.; Han, B.; Mura, M.; Xia, S.; Wang, S.; Ma, T.; Liu, M.; Liu, Z. Angiotensin-converting enzyme inhibitor captopril prevents oleic acid-induced severe acute lung injury in rats. Shock 2007, 28, 106-111. [CrossRef] [PubMed]

42. Gooz, M. ADAM-17: The enzyme that does it all. Crit. Rev. Biochem. Mol. Biol. 2010, 45, 146-169. [CrossRef] [PubMed]

43. Lambert, D.W.; Yarski, M.; Warner, F.J.; Thornhill, P.; Parkin, E.T.; Smith, A.I.; Hooper, N.M.; Turner, A.J. Tumor necrosis factor- $\alpha$ convertase (ADAM17) mediates regulated ectodomain shedding of the severe-acute respiratory syndrome-coronavirus (SARS-CoV) receptor, angiotensin-converting enzyme-2 (ACE2). J. Biol. Chem. 2005, 280, 30113-30119. [CrossRef] [PubMed]

44. Sriram, K.; Insel, P.A. Risks of ACE Inhibitor and ARB Usage in COVID-19: Evaluating the Evidence. Clin. Pharmacol. Ther. 2020, 108, 236-241. [CrossRef]

45. Sriram, K.; Insel, P.A. A hypothesis for pathobiology and treatment of COVID-19: The centrality of ACE1/ACE2 imbalance. Br. J. Pharmacol. 2020. [CrossRef]

46. Dragonetti, D.; Guarini, G.; Pizzuti, M. Detection of anti-heparin-PF4 complex antibodies in COVID-19 patients on heparin therapy. Blood Transfus 2020, 18, 328. [CrossRef]

47. Miesbach, W.; Makris, M. COVID-19: Coagulopathy, Risk of Thrombosis, and the Rationale for Anticoagulation. Clin. Appl. Thromb. Hemost. 2020, 26. [CrossRef]

48. Mazzitelli, M.; Serapide, F.; Tassone, B.; Lagana, D.; Trecarichi, E.M.; Torti, C. Spontaneous and Severe Haematomas in Patients with COVID-19 on Low-Molecular-Weight Heparin for Paroxysmal Atrial Fibrillation. Mediterr. J. Hematol. Infect. Dis. 2020, 12, e2020054. [CrossRef] 
49. Marietta, M.; Vandelli, P.; Mighali, P.; Vicini, R.; Coluccio, V.; D'Amico, R.; Group, C.-H.S. Randomised controlled trial comparing efficacy and safety of high versus low Low-Molecular Weight Heparin dosages in hospitalized patients with severe COVID-19 pneumonia and coagulopathy not requiring invasive mechanical ventilation (COVID-19 HD): A structured summary of a study protocol. Trials 2020, 21, 574. [CrossRef]

50. Lingamaneni, P.; Gonakoti, S.; Moturi, K.; Vohra, I.; Zia, M. Heparin-Induced Thrombocytopenia in COVID-19. J. Investig. Med. High. Impact. Case Rep. 2020, 8. [CrossRef]

51. Chi, G.; Lee, J.J.; Jamil, A.; Gunnam, V.; Najafi, H.; Memar Montazerin, S.; Shojaei, F.; Marszalek, J. Venous Thromboembolism among Hospitalized Patients with COVID-19 Undergoing Thromboprophylaxis: A Systematic Review and Meta-Analysis. J. Clin. Med. 2020, 9, 2489. [CrossRef]

52. Patell, R.; Bogue, T.; Koshy, A.G.; Bindal, P.; Merrill, M.; Aird, W.C.; Bauer, K.A.; Zwicker, J.I. Post-discharge thrombosis and hemorrhage in patients with COVID-19. Blood 2020. [CrossRef] [PubMed]

53. Zhong, W.G.; Wang, Y.; Zhu, H.; Zhao, X. Meta analysis of angiotensin-converting enzyme I/D polymorphism as a risk factor for preeclampsia in Chinese women. Genet. Mol. Res. 2012, 11, 2268-2276. [CrossRef] [PubMed]

54. Purwaningroom, D.L.P.; Saifurrohman, M.; Widodo, N.; Putri, J.F.; Lukitasari, M. Alteration of Splicing Pattern on Angiotensin Converting Enzyme Gene Due To The Insertion of Alu elements. Int. J. Comput. Biol. 2015, 4, 53-58. [CrossRef]

55. Widodo; Wisnasari, S.; Saifur Rohman, M.; Yunita, L.; Lukitasari, M.; Nuril, M.; Holil, K.; Purwaningroom, D.L. Alu insertion/deletion of ACE gene polymorphism might not affect significantly the serum bradykinin level in hypertensive patients taking ACE inhibitors. Egypt. J. Med. Hum. Genet. 2017, 18, 187-191. [CrossRef]

56. Itoyama, S.; Keicho, N.; Quy, T.; Phi, N.C.; Long, H.T.; Ha, L.D.; Ban, V.V.; Ohashi, J.; Hijikata, M.; Matsushita, I.; et al. ACE1 polymorphism and progression of SARS. Biochem. Biophys. Res. Commun. 2004, 323, 1124-1129. [CrossRef]

57. Li, X.; Sun, X.; Jin, L.; Xue, F. Worldwide spatial genetic structure of angiotensin-converting enzyme gene: A new evolutionary ecological evidence for the thrifty genotype hypothesis. Eur. J. Hum. Genet. 2011, 19, 1002-1008. [CrossRef]

58. Marshall, R.P.; Webb, S.; Bellingan, G.J.; Montgomery, H.E.; Chaudhari, B.; McAnulty, R.J.; Humphries, S.E.; Hill, M.R.; Laurent, G.J. Angiotensin converting enzyme insertion/deletion polymorphism is associated with susceptibility and outcome in acute respiratory distress syndrome. Am. J. Respir. Crit. Care Med. 2002, 166, 646-650. [CrossRef]

59. Chiu, R.W.; Tang, N.L.; Hui, D.S.; Chung, G.T.; Chim, S.S.; Chan, K.C.; Sung, Y.M.; Chan, L.Y.; Tong, Y.K.; Lee, W.S.; et al. ACE2 gene polymorphisms do not affect outcome of severe acute respiratory syndrome. Clin. Chem. 2004, 50, 1683-1686. [CrossRef]

60. Chan, K.C.; Tang, N.L.; Hui, D.S.; Chung, G.T.; Wu, A.K.; Chim, S.S.; Chiu, R.W.; Lee, N.; Choi, K.W.; Sung, Y.M.; et al. Absence of association between angiotensin converting enzyme polymorphism and development of adult respiratory distress syndrome in patients with severe acute respiratory syndrome: A case control study. BMC Infect. Dis. 2005, 5, 26. [CrossRef]

61. Jerng, J.S.; Yu, C.J.; Wang, H.C.; Chen, K.Y.; Cheng, S.L.; Yang, P.C. Polymorphism of the angiotensin-converting enzyme gene affects the outcome of acute respiratory distress syndrome. Crit. Care Med. 2006, 34, 1001-1006. [CrossRef] [PubMed]

62. Saab, Y.B.; Gard, P.R.; Overall, A.D. The geographic distribution of the ACE II genotype: A novel finding. Genet. Res. 2007, 89, 259-267. [CrossRef] [PubMed]

63. Pati, A.; Mahto, H.; Padhi, S.; Panda, A.K. ACE deletion allele is associated with susceptibility to SARS-CoV-2 infection and mortality rate: An epidemiological study in the Asian population. Clin. Chim. Acta 2020, 510, 455-458. [CrossRef] [PubMed]

64. Kenyon, C. ACE-1 I/D Polymorphism Associated with COVID-19 Incidence and Mortality: An Ecological Study. Preprints 2020. [CrossRef]

65. Yamamoto, N.; Bauer, G. Apparent difference in fatalities between Central Europe and East Asia due to SARS-COV-2 and COVID-19: Four hypotheses for possible explanation. Med. Hypotheses 2020, 144, 110160. [CrossRef]

66. Smyth, L.J.; Canadas-Garre, M.; Cappa, R.C.; Maxwell, A.P.; McKnight, A.J. Genetic associations between genes in the renin-angiotensin-aldosterone system and renal disease: A systematic review and meta-analysis. BMJ Open 2019, 9, e026777. [CrossRef] 
67. Gemmati, D.; Varani, K.; Bramanti, B.; Piva, R.; Bonaccorsi, G.; Trentini, A.; Manfrinato, M.C.; Tisato, V.; Care, A.; Bellini, T. "Bridging the Gap" Everything that Could Have Been Avoided If We Had Applied Gender Medicine, Pharmacogenetics and Personalized Medicine in the Gender-Omics and Sex-Omics Era. Int. J. Mol. Sci. 2019, 21, 296. [CrossRef]

68. Cao, Y.; Li, L.; Feng, Z.; Wan, S.; Huang, P.; Sun, X.; Wen, F.; Huang, X.; Ning, G.; Wang, W. Comparative genetic analysis of the novel coronavirus (2019-nCoV/SARS-CoV-2) receptor ACE2 in different populations. Cell Discov. 2020, 6, 11. [CrossRef]

69. Strafella, C.; Caputo, V.; Termine, A.; Barati, S.; Gambardella, S.; Borgiani, P.; Caltagirone, C.; Novelli, G.; Giardina, E.; Cascella, R. Analysis of ACE2 Genetic Variability among Populations Highlights a Possible Link with COVID-19-Related Neurological Complications. Genes (Basel) 2020, 11, 741. [CrossRef]

70. Zhao, Y.; Zhao, Z.; Wang, Y.; Zhou, Y.; Ma, Y.; Zuo, W. Single-cell RNA Expression Profiling of ACE2, The Receptor of SARS-CoV-2. Am. J. Respir. Crit. Care Med. 2020. [CrossRef]

71. Cai, G. Bulk and single-cell transcriptomics identify tobacco-use disparity in lung gene expression of ACE2, the receptor of 2019-nCov. medRxiv 2020. [CrossRef]

72. Pinheiro, D.S.; Santos, R.S.; Jardim, P.; Silva, E.G.; Reis, A.A.S.; Pedrino, G.R.; Ulhoa, C.J. The combination of ACE I/D and ACE2 G8790A polymorphisms revels susceptibility to hypertension: A genetic association study in Brazilian patients. PLoS ONE 2019, 14, e0221248. [CrossRef] [PubMed]

73. Wu, Y.H.; Li, J.Y.; Wang, C.; Zhang, L.M.; Qiao, H. The ACE2 G8790A Polymorphism: Involvement in Type 2 Diabetes Mellitus Combined with Cerebral Stroke. J. Clin. Lab. Anal. 2017, 31. [CrossRef] [PubMed]

74. Tognazzo, S.; Gemmati, D.; Palazzo, A.; Catozzi, L.; Carandina, S.; Legnaro, A.; Tacconi, G.; Scapoli, G.L.; Zamboni, P. Prognostic role of factor XIII gene variants in nonhealing venous leg ulcers. J. Vasc. Surg. 2006, 44, 815-819. [CrossRef]

75. Singh, A.V.; Subhashree, L.; Milani, P.; Gemmati, D.; Zamboni, P. Interplay of iron metallobiology, metalloproteinases, and FXIII, and role of their gene variants in venous leg ulcer. Int. J. Low. Extrem Wounds 2010, 9, 166-179. [CrossRef]

76. Pascolo, L.; Gianoncelli, A.; Rizzardi, C.; Tisato, V.; Salome, M.; Calligaro, C.; Salvi, F.; Paterson, D.; Zamboni, P. Calcium micro-depositions in jugular truncular venous malformations revealed by Synchrotron-based XRF imaging. Sci. Rep. 2014, 4, 6540. [CrossRef]

77. Imai, Y.; Kuba, K.; Rao, S.; Huan, Y.; Guo, F.; Guan, B.; Yang, P.; Sarao, R.; Wada, T.; Leong-Poi, H.; et al. Angiotensin-converting enzyme 2 protects from severe acute lung failure. Nature 2005, 436, 112-116. [CrossRef]

78. Yang, M.; Zhao, J.; Xing, L.; Shi, L. The association between angiotensin-converting enzyme 2 polymorphisms and essential hypertension risk: A meta-analysis involving 14,122 patients. J. Renin Angiotensin Aldosterone Syst. 2015, 16, 1240-1244. [CrossRef]

79. Li, Y.Y. Lack of Association of ACE2 G8790A Gene Mutation with Essential Hypertension in the Chinese Population: A Meta-Analysis Involving 5260 Subjects. Front. Physiol. 2012, 3, 364. [CrossRef]

80. Benjafield, A.V.; Wang, W.Y.; Morris, B.J. No association of angiotensin-converting enzyme 2 gene (ACE2) polymorphisms with essential hypertension. Am. J. Hypertens. 2004, 17, 624-628. [CrossRef]

81. Huang, W.; Yang, W.; Wang, Y.; Zhao, Q.; Gu, D.; Chen, R. Association study of angiotensin-converting enzyme 2 gene (ACE2) polymorphisms and essential hypertension in northern Han Chinese. J. Hum. Hypertens. 2006, 20, 968-971. [CrossRef] [PubMed]

82. Zhou, J.B.; Yang, J.K. Meta-analysis of association of ACE2 G8790A polymorphism with Chinese Han essential hypertension. J. Renin Angiotensin Aldosterone Syst. 2009, 10, 31-34. [CrossRef] [PubMed]

83. Patel, S.K.; Velkoska, E.; Freeman, M.; Wai, B.; Lancefield, T.F.; Burrell, L.M. From gene to protein-experimental and clinical studies of ACE2 in blood pressure control and arterial hypertension. Front. Physiol. 2014, 5, 227. [CrossRef] [PubMed]

84. Singh, Y.; Gupta, G.; Mishra, A.; Chellappan, D.K.; Dua, K. Gender and Age Differences Reveal Risk Patterns in COVID-19 Outbreak. Altern. Ther. Health Med. 2020.

85. Ji, L.D.; Li, J.Y.; Yao, B.B.; Cai, X.B.; Shen, Q.J.; Xu, J. Are genetic polymorphisms in the renin-angiotensin-aldosterone system associated with essential hypertension? Evidence from genome-wide association studies. J. Hum. Hypertens. 2017, 31, 695-698. [CrossRef] 
86. Fan, X.H.; Wang, Y.B.; Wang, H.; Sun, K.; Zhang, W.L.; Song, X.D.; Cheng, J.Z.; Wu, H.Y.; Zhou, X.L.; Hui, R.T. Polymorphisms of angiotensin-converting enzyme (ACE) and ACE2 are not associated with orthostatic blood pressure dysregulation in hypertensive patients. Acta Pharmacol. Sin. 2009, 30, 1237-1244. [CrossRef]

87. Yi, L.; Gu, Y.H.; Wang, X.L.; An, L.Z.; Xie, X.D.; Shao, W.; Ma, L.Y.; Fang, J.R.; An, Y.D.; Wang, F.; et al. Association of ACE, ACE2 and UTS2 polymorphisms with essential hypertension in Han and Dongxiang populations from north-western China. J. Int. Med. Res. 2006, 34, 272-283. [CrossRef]

88. Chung, C.M.; Wang, R.Y.; Chen, J.W.; Fann, C.S.; Leu, H.B.; Ho, H.Y.; Ting, C.T.; Lin, T.H.; Sheu, S.H.; Tsai, W.C.; et al. A genome-wide association study identifies new loci for ACE activity: Potential implications for response to ACE inhibitor. Pharm. J. 2010, 10, 537-544. [CrossRef]

89. Ellinghaus, D.; Degenhardt, F.; Bujanda, L.; Buti, M.; Albillos, A.; Invernizzi, P.; Fernandez, J.; Prati, D.; Baselli, G.; Asselta, R.; et al. Genomewide Association Study of Severe Covid-19 with Respiratory Failure. N. Engl. J. Med. 2020. [CrossRef]

90. Breiman, A.; Ruven-Clouet, N.; Le Pendu, J. Harnessing the natural anti-glycan immune response to limit the transmission of enveloped viruses such as SARS-CoV-2. PLoS Pathog. 2020, 16, e1008556. [CrossRef]

91. Murray, G.P.; Post, S.R.; Post, G.R. ABO blood group is a determinant of von Willebrand factor protein levels in human pulmonary endothelial cells. J. Clin. Pathol. 2020, 73, 347-349. [CrossRef] [PubMed]

92. Franchini, M.; Crestani, S.; Frattini, F.; Sissa, C.; Bonfanti, C. ABO blood group and von Willebrand factor: Biological implications. Clin. Chem. Lab. Med. 2014, 52, 1273-1276. [CrossRef] [PubMed]

93. Ohira, T.; Cushman, M.; Tsai, M.Y.; Zhang, Y.; Heckbert, S.R.; Zakai, N.A.; Rosamond, W.D.; Folsom, A.R. $\mathrm{ABO}$ blood group, other risk factors and incidence of venous thromboembolism: The Longitudinal Investigation of Thromboembolism Etiology (LITE). J. Thromb. Haemost. 2007, 5, 1455-1461. [CrossRef] [PubMed]

94. Luo, J.Q.; He, F.Z.; Luo, Z.Y.; Wen, J.G.; Wang, L.Y.; Sun, N.L.; Tang, G.F.; Li, Q.; Guo, D.; Liu, Z.Q.; et al. Rs495828 polymorphism of the ABO gene is a predictor of enalapril-induced cough in Chinese patients with essential hypertension. Pharm. Genom. 2014, 24, 306-313. [CrossRef] [PubMed]

95. Terao, C.; Bayoumi, N.; McKenzie, C.A.; Zelenika, D.; Muro, S.; Mishima, M.; Connell, J.M.; Vickers, M.A.; Lathrop, G.M.; Farrall, M.; et al. Quantitative variation in plasma angiotensin-I converting enzyme activity shows allelic heterogeneity in the ABO blood group locus. Ann. Hum. Genet. 2013, 77, 465-471. [CrossRef]

96. Yamagata University Genomic Cohort, C. Pleiotropic effect of common variants at ABO Glycosyltranferase locus in 9 q32 on plasma levels of pancreatic lipase and angiotensin converting enzyme. PLoS ONE 2014, 9, e55903. [CrossRef]

97. Guillon, P.; Clement, M.; Sebille, V.; Rivain, J.G.; Chou, C.F.; Ruvoen-Clouet, N.; Le Pendu, J. Inhibition of the interaction between the SARS-CoV spike protein and its cellular receptor by anti-histo-blood group antibodies. Glycobiology 2008, 18, 1085-1093. [CrossRef]

98. Zhang, Y.F.; Cheng, Q.; Tang, N.L.; Chu, T.T.; Tomlinson, B.; Liu, F.; Kwok, T.C. Gender difference of serum angiotensin-converting enzyme (ACE) activity in DD genotype of ACE insertion/deletion polymorphism in elderly Chinese. J. Renin Angiotensin Aldosterone Syst. 2014, 15, 547-552. [CrossRef]

99. Zhang, H.; Penninger, J.M.; Li, Y.; Zhong, N.; Slutsky, A.S. Angiotensin-converting enzyme 2 (ACE2) as a SARS-CoV-2 receptor: Molecular mechanisms and potential therapeutic target. Intensive Care Med. 2020, 46, 586-590. [CrossRef]

100. Araujo, F.C.; Milsted, A.; Watanabe, I.K.; Del Puerto, H.L.; Santos, R.A.; Lazar, J.; Reis, F.M.; Prokop, J.W. Similarities and differences of $X$ and $Y$ chromosome homologous genes, SRY and SOX3, in regulating the renin-angiotensin system promoters. Physiol. Genom. 2015, 47, 177-186. [CrossRef]

101. Yuan, X.; Lu, M.L.; Li, T.; Balk, S.P. SRY interacts with and negatively regulates androgen receptor transcriptional activity. J. Biol. Chem. 2001, 276, 46647-46654. [CrossRef] [PubMed]

102. Romero, C.A.; Orias, M.; Weir, M.R. Novel RAAS agonists and antagonists: Clinical applications and controversies. Nat. Rev. Endocrinol. 2015, 11, 242-252. [CrossRef] [PubMed]

103. Arendse, L.B.; Danser, A.H.J.; Poglitsch, M.; Touyz, R.M.; Burnett, J.C., Jr.; Llorens-Cortes, C.; Ehlers, M.R.; Sturrock, E.D. Novel Therapeutic Approaches Targeting the Renin-Angiotensin System and Associated Peptides in Hypertension and Heart Failure. Pharmacol. Rev. 2019, 71, 539-570. [CrossRef] [PubMed]

104. Bakhle, Y.S. How ACE inhibitors transformed the renin-angiotensin system. Br. J. Pharmacol. 2020, 177, 2657-2665. [CrossRef] 
105. Carey, R.M. AT2 Receptors: Potential Therapeutic Targets for Hypertension. Am. J. Hypertens. 2017, 30, 339-347. [CrossRef]

106. Takezako, T.; Unal, H.; Karnik, S.S.; Node, K. Current topics in angiotensin II type 1 receptor research: Focus on inverse agonism, receptor dimerization and biased agonism. Pharmacol. Res. 2017, 123, 40-50. [CrossRef]

107. Guo, X.; Zhu, Y.; Hong, Y. Decreased Mortality of COVID-19 With Renin-Angiotensin-Aldosterone System Inhibitors Therapy in Patients With Hypertension: A Meta-Analysis. Hypertension 2020, 76, e13-e14. [CrossRef]

108. Bonaccorsi, G.; Gambacciani, M.; Gemmati, D. Can estrogens protect against COVID-19? The COVID-19 puzzling and gender medicine. Minerva Ginecol. 2020, 72. [CrossRef]

109. Debnath, M.; Banerjee, M.; Berk, M. Genetic gateways to COVID-19 infection: Implications for risk, severity, and outcomes. FASEB J. 2020. [CrossRef]

110. Dongarwar, D.; Salihu, H.M. COVID-19 Pandemic: Marked Global Disparities in Fatalities According to Geographic Location and Universal Health Care. Int. J. MCH AIDS 2020, 9, 213-216. [CrossRef]

111. Dong, R.; Pei, S.; Yin, C.; He, R.L.; Yau, S.S. Analysis of the Hosts and Transmission Paths of SARS-CoV-2 in the COVID-19 Outbreak. Genes (Basel) 2020, 11, 637. [CrossRef]

112. Goldstein, J.R.; Atherwood, S. Improved measurement of racial/ethnic disparities in COVID-19 mortality in the United States. medRxiv 2020. [CrossRef]

113. Nepomuceno, M.R.; Acosta, E.; Alburez-Gutierrez, D.; Aburto, J.M.; Gagnon, A.; Turra, C.M. Besides population age structure, health and other demographic factors can contribute to understanding the COVID-19 burden. Proc. Natl. Acad. Sci. USA 2020, 117, 13881-13883. [CrossRef] [PubMed]

114. Wang, M.L.; Behrman, P.; Dulin, A.; Baskin, M.L.; Buscemi, J.; Alcaraz, K.I.; Goldstein, C.M.; Carson, T.L.; Shen, M.; Fitzgibbon, M. Addressing inequities in COVID-19 morbidity and mortality: Research and policy recommendations. Transl. Behav. Med. 2020, 10, 516-519. [CrossRef] [PubMed]

115. Helmer, A.; Slater, N.; Smithgall, S. A Review of ACE Inhibitors and ARBs in Black Patients With Hypertension. Ann. Pharmacother. 2018, 52, 1143-1151. [CrossRef] [PubMed]

116. Oliveira-Paula, G.H.; Pereira, S.C.; Tanus-Santos, J.E.; Lacchini, R. Pharmacogenomics And Hypertension: Current Insights. Pharmgenom. Pers. Med. 2019, 12, 341-359. [CrossRef] [PubMed]

117. Zamboni, P.; Gemmati, D. Clinical implications of gene polymorphisms in venous leg ulcer: A model in tissue injury and reparative process. Thromb. Haemost. 2007, 98, 131-137.

118. Lewis, C.M.; Vassos, E. Polygenic risk scores: From research tools to clinical instruments. Genome Med. 2020, 12, 44. [CrossRef]

119. Vuille-dit-Bille, R.N.; Camargo, S.M.; Emmenegger, L.; Sasse, T.; Kummer, E.; Jando, J.; Hamie, Q.M.; Meier, C.F.; Hunziker, S.; Forras-Kaufmann, Z.; et al. Human intestine luminal ACE2 and amino acid transporter expression increased by ACE-inhibitors. Amino Acids 2015, 47, 693-705. [CrossRef]

120. Gasso, P.; Ritter, M.A.; Mas, S.; Lafuente, A. Influence of ABO genotype and phenotype on angiotensin-converting enzyme plasma activity. J. Renin Angiotensin Aldosterone Syst. 2014, 15, 580-584. [CrossRef]

121. Ling, Y.; van Herpt, T.T.; van Hoek, M.; Dehghan, A.; Hofman, A.; Uitterlinden, A.G.; Jiang, S.; Lieverse, A.G.; Bravenboer, B.; Lu, D.; et al. A genetic variant in SLC6A20 is associated with Type 2 diabetes in white-European and Chinese populations. Diabet. Med. 2014, 31, 1350-1356. [CrossRef] [PubMed]

(C) 2020 by the authors. Licensee MDPI, Basel, Switzerland. This article is an open access article distributed under the terms and conditions of the Creative Commons Attribution (CC BY) license (http://creativecommons.org/licenses/by/4.0/). 